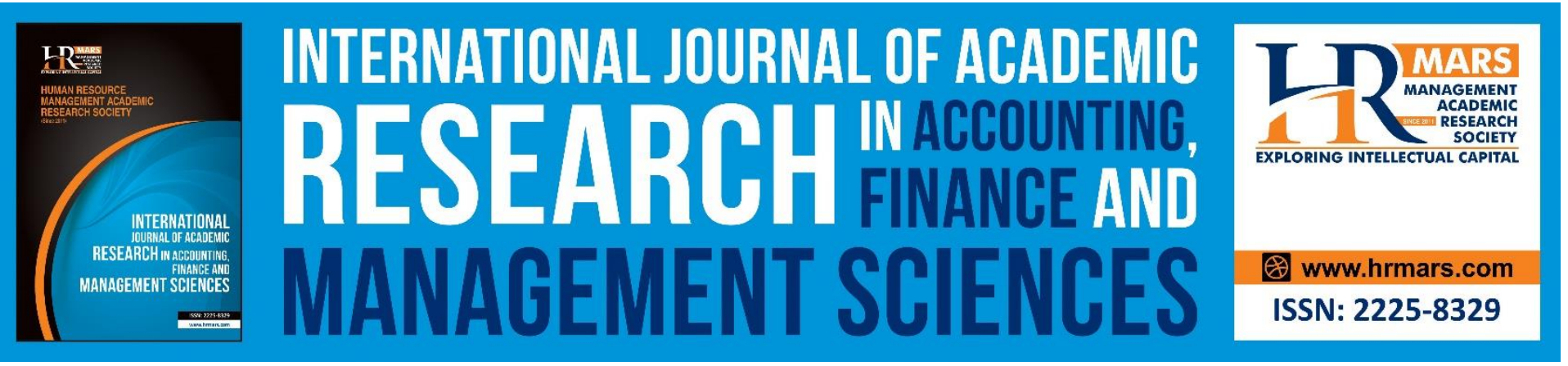

\title{
A Preliminary Study of Islamic Financial Well-Being Index
}

\section{Nurul Nadia Abd Aziz, Mohd Samsuri Ghazali, Siti Fahazarina Hazudin, Sharifah Faigah Syed Alwi}

To Link this Article: http://dx.doi.org/10.6007/IJARAFMS/v10-i3/7633

DOI:10.6007/IJARAFMS /v10-i3/7633

Received: 01 June 2020, Revised: 29 July 2020, Accepted: 26 August 2020

Published Online: 24 September 2020

In-Text Citation: (Abd Aziz, Ghazali, Hazudin, \& Alwi, 2020)

To Cite this Article: Abd Aziz, N. N., Ghazali, M. S., Hazudin, S. F., \& Alwi, S. F. S. (2020). A Preliminary Study of Islamic Financial Well-Being Index. International Journal of Academic Research in Accounting, Finance and Management Sciences. 10(3), 176-192.

\section{Copyright: (c) 2020 The Author(s)}

Published by Human Resource Management Academic Research Society (www.hrmars.com)

This article is published under the Creative Commons Attribution (CC BY 4.0) license. Anyone may reproduce, distribute, translate and create derivative works of this article (for both commercial and non-commercial purposes), subject to full attribution to the original publication and authors. The full terms of this license may be seen at: http://creativecommons.org/licences/by/4.0/legalcode

Vol. 10, No. 3, 2020, Pg. 176 - 192

http://hrmars.com/index.php/pages/detail/IJARAFMS

Full Terms \& Conditions of access and use can be found at http://hrmars.com/index.php/pages/detail/publication-ethics 


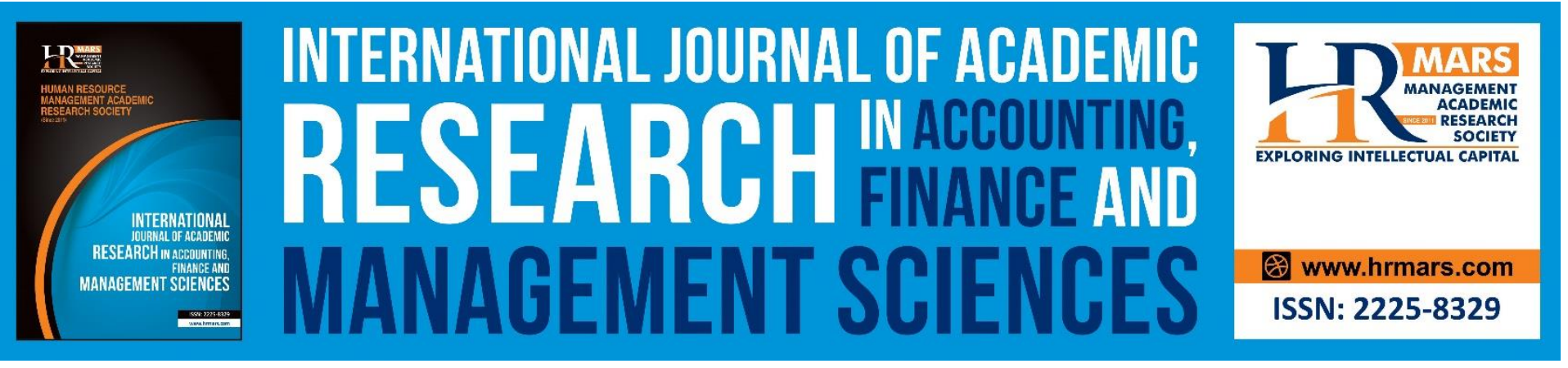

\title{
A Preliminary Study of Islamic Financial Well-Being Index
}

\author{
Nurul Nadia Abd Aziz¹, Mohd Samsuri Ghazali², Siti Fahazarina \\ Hazudin ${ }^{3}$, Sharifah Faigah Syed Alwi ${ }^{4}$ \\ 1,2 Faculty of Business and Management, Universiti Teknologi MARA Pahang (Raub Campus), \\ Pahang, Malaysia, ${ }^{3}$ Faculty of Business and Management, Universiti Teknologi MARA Pahang \\ (Jengka Campus), Pahang, Malaysia, ${ }^{4}$ Arshad Ayub Graduate Business School, Universiti Teknologi \\ MARA Shah Alam, Selangor, Malaysia \\ Email:nurul_nadia@uitm.edu.my
}

\begin{abstract}
This study aimed to explore the criteria of the financial well-being of the Malaysian workforce to develop a conceptual understanding of the impaired financial well-being of young adults. Concurrently, this study aimed to develop an Islamic Financial Well-Being Index (i-FWB Index) for sustainable financial well-being among Malaysian workers in consideration of recent transformative innovation in Islamic financial services. The orientation of qualitative research fitted the objective of this study, which was to conceptualise on the limited literature on Islamic economic well-being. The utilisation of individual and focus group interviews in gathering expert opinions provided valuable data based on grounded theory to develop a substantive and conceptual analysis. Atlas.ti was used as the software for qualitative analysis to achieve the research objective. Since none has touched on the area of developing financial well-being with the inclusion of religious beliefs, the findings of this study are expected to bridge the gap by providing specific scale in measuring Islamic financial wellbeing index, specifically for Malaysian workers. The originality of this study may contribute to the formation of a new body of knowledge, and enrich the literature sources in the field of scale development that will benefit the academicians.
\end{abstract}

Keywords: Attitude, Knowledge, Financial Well-Being, Religious Beliefs, Self-Control.

\section{Introduction}

Financial well-being is the primary factor that affects personal well-being (O'Neill et al., 2005). The individual who can handle their finances well will maintain positive well-being (Rutherford \& Fox, 2010). However, disturbance towards individuals' financial well-being will cause a long-term ramification on their psychological, emotional, and relational well-being (Neyber, 2016). There are three leading indicators in evaluating the financial well-being which include the amount of future saving (Finney, 2016), level of debt (Finney, 2016), and bankruptcy rate (Xiao, 2013). However, the occurrence in Malaysia indicates the alarming level of financial well-being in the country. Murugiah 
INTERNATIONAL JOURNAL OF ACADEMIC RESEARCH IN ACCOUNTING, FINANCE AND MANAGEMENT SCIENCES

Vol. 10, No. 3, 2020, E-ISSN: 2225-8329 ๔ 2020 HRMARS

(2016) claimed that Malaysian household debt is at a red flag level despite dropping to 84.6 per cent in 2017, from 88.4 per cent in 2016 (Bank Negara Malaysia, 2017). Furthermore, the Malaysia Insolvency Department (2018) declared bankruptcy on 300,958 individuals in Malaysia due to their failure to settle numerous financial commitments such as hire-purchase, credit cards, personal loan, housing loan, and social guarantor debts (due to errant debtors). This step may result in increasing financial stress and eventually may reducing financial well-being.

To date, there are several types of indices that were developed to measure financial well-being. The first index was the CFPB Financial Well-Being Scale, which was founded by Prendergast, et al. (2018). This index was developed to estimate an overall financial well-being score that takes into consideration the factors that may influence the financial well-being, namely, behaviour, knowledge, experience, attitudes, motivations, and environmental factors. However, this index was developed by taking into account the lifestyles of American residents only. The second index was Saver Plus, which was developed by Russell et al. (2015). This index was developed with the primary goal is to help participants create and maintain a savings habit, build financial resilience and improve financial capabilities. Again, this index was also developed to suit the American residents.

In Malaysia, many types of research on well-being have been carried out by the Economic Planning Unit, the Prime Minister's Department, Putrajaya. These are some indices developed by many institutions in Malaysia: 1) Malaysian Well-being Index (Economic Planning Unit, 2000), 2) Malaysian Youth Index (Malaysian Institute for Research in Youth Development, 2006), 3) Family Well-being Index (National Population and Family Development Board, 2011), 4) Working Quality of Life Study (Malaysian Productivity Corporation, 2012), 5) Muslim Ummah Development Index (Institute of Islamic Understanding, 2016). Some indices are still under progress, namely the Multi-dimensional Poverty Index (Economic Planning Unit), National Unity Index (Department of National Unity and Integration), and Happiness Index (Ministry of Finance).

While various agencies have developed many indices within and outside the country, the index that specialises in the measurement of sustainable financial well-being is still unclear. It is not appropriate to measure the financial well-being of Malaysian society using the CFPB Financial Well-Being Scale and Saver Plus, which have been developed specifically for the American residents. Furthermore, other indexes used by researchers and institutions in Malaysia are not explicitly designed for the measurement of sustainable financial well-being. Instead, they measured the well-being of society in general by inserting some financial elements.

The only instrument that measures financial well-being for Malaysian people is Malaysian Personal Financial Well-being Scale (MPFW), which was developed by Masud (2007). This instrument consists of 12 items, which includes attitude, behaviour, control, and confidence. This instrument, however, does not contain the element of religious beliefs, which is one of the components of psychological factors (Ghazali et al., 2020). According to Shweder (1991), religion is one of the most universal and influential social institutions. It has a significant influence on people's attitudes, values, and behaviours at both the individual and societal levels. Religious beliefs and associated practices often play a pivotal role in influencing how individuals cope with critical life transitions. However, little research has examined the effect of religious beliefs on financial behaviour, financial knowledge, or financial well-being (Fazli, 2015). Thus, the current study intends to fulfil the research gap by developing a new financial well-being index with the involvement of religious beliefs elements. Since religious beliefs may act as the behavioural control of an individual and are expected to affect 
INTERNATIONAL JOURNAL OF ACADEMIC RESEARCH IN ACCOUNTING, FINANCE AND MANAGEMENT SCIENCES

Vol. 10, No. 3, 2020, E-ISSN: 2225-8329 @ 2020 HRMARS

sustainable financial well-being; thus the involvement of this element in a new financial well-being index will become the main contribution of this study.

The instrument to be developed is more suitable to be named as Islamic Financial Well-Being Index (hereafter referred to as i-FWB Index); it includes religious beliefs as an Islamic religion element in measuring sustainable financial well-being for people in Malaysia. Malaysia is now becoming the world's first hub for Islamic financial products, hence the development of i-FWB Index is indispensable and timely. In short, the current study takes into account the factors that may influence the sustainable financial well-being, which are behaviour (spending, saving, retirement, investment and debts management), attitude, knowledge, self-control, and religious beliefs.

Therefore, the main objective of this study is to identify the criteria of the financial well-being of the Malaysian workers and to assess the validity of the Islamic Financial Well-Being Index (i-FWB Index) in measuring the sustainable financial well-being of Malaysian workers. This study will involve three phases: 1) the identification of the factors that may lead to the sustainable financial well-being of Malaysian workers, 2) the development of i-FWB Index, 3) the assessment of the validity of i-FWB Index in measuring the sustainable financial well-being of Malaysian workers.

\section{Literature Reviews}

\section{The Definition of Financial Well-Being}

Currently, there are various definitions of financial well-being, which were derived from previous research. The earliest meaning was theorised by Williams (1993) as the objective and subjective measurement of an individual's financial position. Joo (2008) in a later study stated that financial well-being is the basic concept of financial health that can be measured through the level of material and non-material aspects of financial security, the perception of financial stability, and the actual amount of financial resources. Local researchers (Zaimah et al., 2013) concurred with the previous definitions that posited the subjective and objective elements of a person's financial situation in their interpretation.

In addition, the CFPB (2015) in a qualitative study concluded that financial well-being could be achieved when individuals can meet their current and future financial responsibilities, have no worries about their financial future and can make a clear financial decision for the enjoyment of life. This definition is parallel with Kempson et al. (2017), who opined the term as a person who can meet all his/her current financial engagements and has the financial resilience to maintain in the future. Stromback et al. (2017) held a similar premise and concluded that three elements should be used to measure financial well-being, which is secure with the present financial situation, particular about the future financial situation, and have sufficient fund for retirement. From those definitions, the researchers conclude that there are two aspects in measuring financial well-being, namely, objective and subjective elements. The researchers also agree that the financial well-being measurement should include three components, which are the current financial situation, future financial resilience, and financial freedom to enjoy life.

"Subjective financial well-being" is the expression used to determine the non-material aspect of a person's financial situation. Previous researchers often used different terminologies in evaluating an individual's subjective financial well-being. According to Sumarwan and Hira (1992), examples of the terms used were "satisfaction with savings level", "debt level preparedness", "satisfaction with financial emergency preparedness", "current financial situation", "ability to meet long-term goals", 
INTERNATIONAL JOURNAL OF ACADEMIC RESEARCH IN ACCOUNTING, FINANCE AND

MANAGEMENT SCIENCES

Vol. 10, No. 3, 2020, E-ISSN: 2225-8329 ๑ 2020 HRMARS

"readiness to meet emergencies", and "skills in financial management". Besides, the levels of financial distress perceived financial well-being, and financial security was also regularly used (Fazli, 2013).

\section{The Instruments Used in Measuring Financial Well-Being} CFPB Financial Well-Being Scale (Prendergast et al., 2018)

The CFPB Financial Well-Being Scale was developed using modern measurement theory analyses (including factor analysis and IRT modelling). This instrument covers all four elements of the CFPB's definition of financial well-being: control over finances, capacity to absorb a financial shock, being on track to meet financial goals, and having the financial freedom to enjoy life. This measurement was used to uncover specific types of knowledge, skills, behaviour, and attitudes to help people in improving their financial well-being and moving consumer financial capability-building practices forward in ways that can benefit American consumers. The weakness of this instrument is that it is developed by taking into account the lifestyles of American residents only. Therefore, this instrument is not appropriate to be adopted in measuring sustainable financial well-being for Malaysians because Malaysia is inhabited by multiracial and multi-religious community.

\section{Saver Plus (Russell et al., 2015)}

Saver Plus was developed by Russell et al. (2015). This index was developed with the primary goal to help participants create and maintain a savings habit, build financial resilience and improve financial capabilities. Again, this index was also developed to suit the American residents. This instrument is not suitable to be used in measuring sustainable financial well-being for Malaysians because saving is only one of the elements of financial behaviour.

\section{Personal Financial Well-Being Scale (Prawit et al., 2006)}

The most widely used scales in assessing the perception of the financial well-being of an individual is known as Personal Financial Well-Being Scale (PFW). This instrument was developed by Prawitz et al. (2006) from South Africa. The main objectives of this scale are to measure the perception of financial well-being and the accompanying stress due to the financial status of the respondents. PFW is a brief scale which consists of only eight items, and each item is arranged as a continuum (extending from negative to positive feeling) in 10-point Likert's scales, which inquire the respondent's financial wellbeing. The higher scores indicate the highest financial well-being or no financial distress, while the lower scores indicate the lowest financial well-being or overwhelming financial distress.

Generally, this scale measures two main aspects with four items measuring the current sense of financial well-being, and the other four is about how one reacts to their present financial well-being. The items are an extension from previous research with the addition of the elements of attitude, knowledge, control, and confidence regarding financial matters. The scale was constructed as factor analysis and was later known as the "Personal Financial Well-being Scale" (PFW). It has been used and validated by researchers until the present time (Kempson et al. 2017). In PFW, the questions asked to respondents include how often they have insufficient money and how confident they are about their future unexpected expenses. Kempson et al. (2017) study, however, underline the importance of considering the context in conceptualising financial well-being and why country- 
INTERNATIONAL JOURNAL OF ACADEMIC RESEARCH IN ACCOUNTING, FINANCE AND

MANAGEMENT SCIENCES

Vol. 10, No. 3, 2020, E-ISSN: 2225-8329 @ 2020 HRMARS

specific approaches may be needed. In conjunction with that, it implies that there is a need to have a specific instrument to measure the financial well-being that suits Malaysians.

\section{Malaysian Personal Financial Well-being (MPFW)}

In Malaysia, a specific scale known as the Malaysian Personal Financial Well-being (MPFW) scale is used to suit the Malaysian environment. It was developed by Masud in 2007 because PFW is only available in English. Hence, MPFW is developed in Malay language to be adapted into Malay populations in Malaysia. MPFW was developed based on the PFW scale but with more dimensions that are suitable for the Malaysian culture. The instrument consists of 12 items, which includes attitude, behaviour, control, and confidence to measure the Malaysian family's financial situation. The local studies (Husniyah \& Fazilah, 2011; Sabri \& Falahati, 2003) also used the MPFW scale to predict financial well-being among Malaysian workers. The measurements of MPFW are on a 10point Likert's scale. The scores were summated and averaged. The lower average scores indicate poorer average financial well-being, while higher average scores indicate better average financial well-being.

\section{Islamic Financial Well-Being Index (i-FWB Index)}

Based on four instruments above, the current study found that there was a lack of religious elements in measuring sustainable financial well-being. Therefore, the present study intended to bridge the gap by developing an Islamic Financial Well-Being Index (i-FWB Index) in measuring sustainable financial well-being for Malaysian people. In short, the current study took into account the factors that may influence the sustainable financial well-being, which were behaviour (spending, saving, retirement, investment and debts management), attitude, knowledge, self-control, and religious beliefs.

\section{Financial Behaviour}

Financial behaviour is a term used to evaluate an individual's financial management. According to Xiao et al. (2013), financial behaviour is an individual character that is relevant to money management. It is also a money management practice that is guided by financial custom and other variables (Chaulagain, 2015). The measurement of financial behaviour is different according to researchers' motivation. The measurement is based on dimensions such as the level of saving, the management of cash flow, investment, risk management, and financial planning. Robb and Woodyard (2011) found that cash or credit management, retirement, risk management, and emergency saving are good indicators for evaluating personal financial behaviour. Meanwhile, the study by Xiao et al. (2004) covered four aspects of financial management, which were cash-flow, retirement, credit, and financial planning. The study revealed that good financial practice would contribute to a good pension plan.

Hilgert and Hogarts (2003) employed four financial behaviour activities, which were cash-flow management, investment, saving, and debt management to investigate the ways household manage their financial activities. They also categorised financial behaviour into high (more than 70 per cent score), medium (25 to 70 per cent score), and low (below 25 per cent). Xiao and colleagues (2013) presented a scale that evaluated an individual into two categories, which were positive (desirable) 
INTERNATIONAL JOURNAL OF ACADEMIC RESEARCH IN ACCOUNTING, FINANCE AND MANAGEMENT SCIENCES

Vol. 10, No. 3, 2020, E-ISSN: 2225-8329 ๔ 2020 HRMARS

and negative (undesirable) financial behaviours. The result revealed that desirable financial behaviour contributed to higher financial well-being and vice versa.

The majority of the scholars agreed that financial behaviour is the primary determinant of financial well-being. The studies by Shim et al. (2009) and Xiao et al. (2013) that used financial satisfaction as a proxy for financial well-being revealed that financial behaviour was the main predictor. O'Neill et al. (2005) argued that a person who displayed negative financial behaviour such as delaying credit card payments would have lower financial wellness. Meanwhile, Joo (2008) declared that financial behaviour was the dominant contributor to an individual's financial well-being status. Therefore, good financial behaviour has a positive effect on financial well-being (Shim et al., 2009; Xiao, 2004), whereas poor financial management has a negative impact on financial well-being (Kim et al. 2003). The studies conducted by local researchers also showed significant results. According to Sabri and Falahati (2003), apart from income and financial knowledge, financial behaviour is the most influential factor for financial well-being. The same result was revealed by Mokhtar and Husniyah (2017) in their study on Malaysian civil servants in Putrajaya, which proved that financial behaviour is the prominent factor of financial well-being. They suggested that an efficient way to increase financial well-being was through good financial management practice. The study by AFBes'18 (2018), Othman (2017), Mokhtar and Husniyah (2017) also revealed that financial well-being would increase parallel to positive financial behaviour. In short, higher financial behaviour is associated with higher financial well-being.

\section{Financial Attitude}

Financial attitude refers to the judgment, opinion, and what a person thinks about financial matters (Halim \& Astuti, 2015). For example, good thought on financial issues will increase the desire to save, plan, and invest money for a bright future. Besides, someone who perceives money as something valuable will have a good attitude that later can increase financial satisfaction and improve overall well-being. An excellent financial attitude will help an individual to make a sound financial management decision. The positive impact on financial behaviour occurs when a person has a higher financial attitude.

However, very few studies have explored the effect of financial attitude on financial behaviour (Chen et al., 2018). For instance, a survey by Hayhoe et al. (2005) stressed that a good financial attitude would change an individual's financial behaviour. Subsequently, a study by Bir (2016) on financial practice among young graduates suggested that financial attitude has a more significant influence on financial behaviour. The research conducted by Amanah et al. (2016) claimed that financial attitude partially affects financial management behaviour. A few researchers (Herdjiono \& Darmanik, 2016) also expressed that there was a positive influence of financial attitude on financial management behaviour. Ibrahim and Alqaydi (2016), in their study on personal debts among the United Arab Emirates residents, indicated that a robust financial attitude would lead to less desire to use a credit card. A local study in Malaysia conducted on employees as respondents supported the hypotheses that financial attitude influenced financial behaviour by $23 \%$ (Shafinar et al., 2017). The study by Chen et al. (2018) also paralleled with previous studies. In contrast, only one study, which was done by Novita and Maharani (2016) argued that financial attitude had no effect on financial management behaviour. 
INTERNATIONAL JOURNAL OF ACADEMIC RESEARCH IN ACCOUNTING, FINANCE AND

MANAGEMENT SCIENCES

Vol. 10, No. 3, 2020, E-ISSN: 2225-8329 ๔ 2020 HRMARS

\section{Financial Knowledge}

Garmen and Forgue (2006) stated that financial knowledge is the understanding of the concept, principle, facts, and technology tools that can be used to increase knowledge and be more expert about money management. According to Huston (2010), the words financial literacy, financial knowledge, and financial education were used interchangeably as part of academic literature or media. Prior studies claimed that the level of financial knowledge in developing countries is lower than in developed countries (Beckmann, 2013; Klapper \& Panos, 2011). Many articles focused on the relationship between financial knowledge and financial behaviour (Lusardi \& Mitchell, 2011; Jappelli \& Padula, 2011), but there are mixed findings on the relationship which are not always proven as a causal relationship. Hastings et al., (2013) stated that a relationship was not even necessarily implied. The majority of the previous studies demonstrated a positive correlation between financial knowledge and financial behaviour. Hilgert et al. (2003) proved that there was a positive relationship and concluded that if financial knowledge was internalised, it could lead to accepted financial behaviour.

The local study by Chen et al. (2018) revealed a positive relationship between financial knowledge and financial behaviour among young working adults in Malaysia and suggested that financial knowledge promoted high financial behaviour. The study by Nelson et al. (2018) that used millennial as respondents also obtained significant results. They suggested that future studies should consider the potential of financial knowledge to improve financial behaviour in order to face the challenges related to financial stress with wisdom and a matured manner. Furthermore, Sabri and Falahati (2003) claimed that financial knowledge had a good impact on financial management with the ability to improve the level of financial prosperity. Lastly, two studies used different respondents and contexts (Sabri \& Falahati, 2003; Mokhtar \& Husniyah, 2017). Yet, the results showed that financial knowledge had a vital role in one's financial behaviour.

Nevertheless, according to Hastings et al., (2013), the relationship between financial knowledge and financial behaviour has not always been proven as a causal relationship. Bir (2016) revealed that financial knowledge was not significant in predicting financial management practices. For example, the study by Finney (2016) claimed that higher financial knowledge would result in more deficient credit management. Other studies (Asaad, 2015; Bruin et al. 2012) stressed that a person who has good knowledge did not necessarily acquire good financial management skill.

\section{Self-Control}

Several studies in the financial management field focused on self-control. However, those studies were mainly conducted in the psychology field. According to Baumeister (2002) and Fujita et al. (2006), self-control is the ability to break bad or negative habits, resist temptations, and overcome the feelings of urgency (first impulses). Additionally, self-control is the ability of future events to control the present circumstances. After a failure of self-control, people will act in an unpleasant way, for instance, procrastinate at work even at the tasks they are good at (Fudenberg \& Levine, 2006). To ensure long-term success in many areas of life, one should have the ability to control impulses that were found to be the undoubted key factor.

The studies that explored the relationship between self-control and financial behaviour have been focusing on specific financial decisions, such as credit usage and retirement planning. Achtziger et al. (2015) stated that low self-reported self-control people were likely to indulge in compulsive 
INTERNATIONAL JOURNAL OF ACADEMIC RESEARCH IN ACCOUNTING, FINANCE AND MANAGEMENT SCIENCES

Vol. 10, No. 3, 2020, E-ISSN: $2225-8329$ ¿ 2020 HRMARS

shopping. Meanwhile, Gathergood (2012) found that those with self-control issues in their financials were more likely to experience credit withdrawals and unpredicted expenses, leading to overindebtedness. Other than that, self-control will give effect to people's savings behaviour. Biljanovska and Palligkinis (2015) stated that households that lacked planning, monitoring, or commitment initially had self-control issues, and this would lead to a low level of wealth accumulation. People with little self-control have problems in their savings, especially for their retirement (Choi et al., 2011). Rha et al. (2006) used a set of data from a survey conducted on American representatives to test the process of self-control mechanisms like saving objectives, expected billable, and savings rules that directly affected the household's savings behaviour. It was found that those with saving rules had more savings than those without savings rules. On the other hand, Ballinger et al. (2011) found that neither self-control nor the four different kinds of impulsive behaviour measurements affected savings behaviour when taking cognitive abilities like working memory into consideration.

Even though the self-control has significant effects on financial decision behaviour, the relationship between self-control and financial well-being is still underexplored in previous literature. Stromback et al. (2017) stated that self-control affects both aspects of financial well-being (financial anxiety and security), and apart from that, it has a positive association with good financial behaviour. Plus, it has a positive effect on financial security, but a negative effect on financial anxiety. Nonetheless, Stromback et al. (2017) proposed that to get a better understanding, future researchers should explore if self-control had a mediating or moderating effect on financial well-being.

Albeit there is no moderating effect study done on the relationship between financial behaviour and financial well-being, several studies conducted in the psychology field had explored the moderation effect of self-control on the relationship among behaviour, well-being, and stress. In a survey conducted by Qutaibaa and Tamie (2010), they found that self-control moderated the relationship between aggressive behaviour and low subjective well-being. They also added the importance of developing self-control to reduce aggressive behaviour. Abuseif and Abdullah (2016) showed that self-control moderated the relationship between anger traits and workplace bullies. Therefore, this study will expand the suggestion by Stromback et al., (2017) by adding self-control as a moderating variable in the relationship between financial behaviour and financial well-being.

\section{Religious Beliefs}

Religion plays a pivotal role in the life of an individual, society and national development, mainly in the sense that religion provides a solution to the betterment of life (e.g., cure emotional discomforts, encourage moral upstanding, promotes stability and harmony). The way religion is so attached to humankind is the role it played in shaping one's thinking and actions. It stipulates, among others, a code of conduct to guide the believers to behave ethically and be socially responsible (Yilmaz \& Bahçekapili, 2015). In India, religion is considered as a critical factor to build their national model for people happiness (Moltafeta et al., 2010). Similar to Malaysia, religion is accounted as a central construct to predict Family Well-being Index (Ministry of Women, Family and Community Development).

The effects of religion on a person's behavioural norms have been discussed in many research works. Mainly, the religious-behavioural concept has been explained as a correlational to psychological variables. The outcomes from these areas of studies have pointed so far to be favour on the religiousness functional. Cohen et al. (2008) had found a significant relationship between people with 
INTERNATIONAL JOURNAL OF ACADEMIC RESEARCH IN ACCOUNTING, FINANCE AND MANAGEMENT SCIENCES

Vol. 10, No. 3, 2020, E-ISSN: 2225-8329 ๑ 2020 HRMARS

intense religiousness and their ability to achieve greater life satisfaction compared to people with weak religiousness level. It can be expected as people live based on the need to desire a purposeful meaning of life (Abeyta \& Routledge, 2018). Their work had proven that people with religiousminded tend to achieve a greater sense that their life is happier than before. As for Muslims, it has been clearly stated in Quran, the purpose of life is no other than to worship Allah, which mean to surrender oneself by performing all acts of obedience to God. The concept of practising genuine religiosity in Islam has helped people to direct their goal-centred into attaining grateful meaning of life.

Another researcher has found a strong connection between religiosity and people's functional ability (Javanmard, 2013)., To some extent, religiosity also influences how people make a deal in investment undertakings. Recent work by Misra et al. (2019) highlighted the significant contributions of the religiosity in promoting superior ability to make rational and intuitive decision making with emotionally sound controlled in investment activities compared to the lower religiosity investors. Furthermore, it is worth to mention here that the people with a lower level of religiosity tend to have a higher desire to spent on material goods (Stillman et al., 2012). As such, we could speculate that there is a tendency that their ability to make a wise decision in economics and financial settings might give room for a potential disaster. It makes sense as Sipon et al. (2014) has shown in their study that people with lower religious consumed more debt and resulted in higher debt stress level. All these support why Islam has put serious concern on financial management, in particular, debt consumption.

This study has adequately justified why the development of sound personal financial well-being index should include the construct of religiosity concept for a reliable measurement instrument. The role of religion construct has been suggested by Chen et al., (2016) to be considered as a critical social mechanism to combat opportunistic behaviour in bank loan contract by borrowers. Having religious considerations engagement towards a higher ethical standard in loan consumption activities can be realised.

\section{Methodology \\ Research Design}

Since the objective of this study is to explore the criteria for the sustainable financial well-being of Malaysian workers, then the use of qualitative methods such as interviews and focus groups is appropriate to find new ideas and insights of young adults. The procedure used to develop the Islamic Financial Well-Being Index (i-FWB Index) mostly followed the guidelines recommended by previous researchers (Wotruba \& Wright, 1975; Churchill, 1979; DeVellis, 1991). With reference to these researchers, the current study concludes that there are five significant steps in developing i-FWB Index: (1) generation an item pool, (2) qualitative data analysis, (3) scale development, (4) panel of experts review, (5) identification of the new model of i-FWB Index.

\section{Generate an Item Pool}

There are two basic methods to generate an item pool, namely deductive and inductive. Deductive scale development method requires a comprehensive review of the literature to understand the constructs. In contrast, an inductive scale development method is needed when there is insufficient theory to underpin the identification of the construct. Thus, for item generation, this study will use 
(1) review of relevant literature related to existing theoretical and empirical research of financial wellbeing, (2) exploratory method which is conducting a focus group with Malaysian workers. The selection of these methods are in line with Selltiz et al., (1976), who suggest that the item generation can be done through exploratory research (e.g., focus group or open-ended interviews) and literature searches. This method has been used extensively by many previous researchers in order to generate an item pool (DeVellis, 1991).

The current study has referred to several studies (Biljanovska \& Palligkinis, 2015; Herdjiono \& Darmanik, 2016; Othman, 2017; Xiao, 2004; Gathergood, 2012) that discuss the factors that may influence the financial well-being. The purpose of referring to these qualitative studies is to gain an initial overview of the antecedents of financial well-being. From the literature search, we found that the criteria of financial well-being are influenced by financial behaviour, financial attitude, financial knowledge, and self- control.

For exploratory methods, the researchers intend to have a discussion with focus groups of workers from the B40 category. The respondents will be purposively selected based on three main criteria: 1) he/she must work in the public sector, 2) aged between 35 to 45 years old, 3) from the B40 category, which is having a monthly average household income below than RM3,860. However, B40 households with an average income below the National Poverty Line of RM980 are excluded from the scope of this study. The purpose is to capture participants' experience, perception, and attitude. The goal in conducting these groups is to enable participants to share their thought about the factors that may contribute to financial distress. The information gathered will be used to determine the criteria of the financial well-being of Malaysian workers. Focus group will be continued until the data became saturated, where there was no longer any significant additional information.

To ensure the validity of this research, a set of the semi-structured questionnaire will be used in the discussion, and the participants will be encouraged to express their views at length. The examples of open-ended questions that will be asked to the participants during the focus group discussion are: 1) "How often do you run short of money for food and other regular expenses?", 2) "How well do you think this statement fits you personally - My finances allow me to do the things I want and enjoy in life?", 3) "If your income fell by a third, for how long could you meet all your expenses without needing to borrow?".

\section{Qualitative Data Analysis}

The next step is to analyse the qualitative data using Atlas.ti software. Initially, this involved transcribing the audio recordings of interviews. The data will be continually analysed as part of the research process to align theory with the findings. All data uploaded into Atlas.ti will be then coded to identify themes. Once themes were identified from the data, they will be compared to those reported in the literature about financial well-being. A line-by-line analysis will be undertaken, and passages of text will be coded to one or many codes. Themes about the experience with financial distress, financial attitude, financial behaviour, knowledge and self-control, will be first identified, with other themes uncovered during the coding process. Emergent themes will be generated as patterns or "occurrences" that will be identified during the process and begin to act as a link to new or emergent patterns in the data. Then the theory is subsequently developed to explain these factors. 
INTERNATIONAL JOURNAL OF ACADEMIC RESEARCH IN ACCOUNTING, FINANCE AND

MANAGEMENT SCIENCES

Vol. 10 , No. 3, 2020, E-ISSN: $2225-8329$ @ 2020 HRMARS

\section{Scale Development}

The first draft of questionnaire will be designed to assess the content validity and clarity of the items. This study intends to use a Likert scale format for the development of I-FWB Index. Likert scale is the most common format used by many researchers in the field of scale development. Using a Likert's scale format, the items will be presented in the form of verse statements, followed by response options that indicate various degrees of agreement or confirmation of the statement (DeVellis, 1991).

\section{The Panel of Experts Review}

The next step in developing i-FWB Index is by appointing a few panel experts from the academicians and a few representatives from Debt Management and Counselling Agency, to validate the contents of the first draft questionnaire. Content validity of a measuring instrument is defined as the extent to which it provides adequate coverage of the topic. The panel experts will be asked to indicate the extent to which each item is appropriate to measure criteria of financial well-being according to the scale ranging from (1) "need improvement" to (3) "exemplary". The panel experts also will be asked to indicate the extent to which the item describes the criteria of sustainable financial well-being according to the scale ranging from (1) "yes, definitely describes the criteria of sustainable financial well-being" to (3) "no, definitely does not describe the criteria of sustainable financial well-being".

\section{Identification of the New Model of i-FWB Index}

After the panel of expert reviewers have validated the content of the questionnaire, the modification and purification of the instruments will be finalised by the researchers.

\section{Theoretical and Practitioners Contributions}

Since none has touched on the area of developing financial well-being with the inclusion of religious beliefs, the findings of this study are expected to bridge the gap by providing specific scale in measuring Islamic financial well-being index, specifically for Malaysian workers. The originality of this study may contribute to the formation of a new body of knowledge, and enrich the literature sources in the field of scale development that will benefit the academicians. Besides, this study may serve as a starting point for further researchers in measuring financial well-being, which in turn, may stimulate new research that will include modification and improvement of the scale through continued testing. A reliable and accurate measurement to be derived from the results of this study may be used by future researchers to conduct a series of examination using quantitative approaches, focusing on determining the antecedents of financial well-being.

The results of this study are expected to provide a validated tool that may be used to assist in the Government Transformation Plan associated with an increasing economic impact of government servants for greater social well-beings. Moreover, the results provide access towards the high-income nation, benefit the country profile and enhance the Malaysia capabilities world-wide. This study is relevant in supporting the Malaysia New Economy Policy (NEP) to reduce and eradicate poverty irrespective of race through increasing income level and purchasing power, sustaining employment opportunities for all citizen, as well as correcting the economic imbalance. Furthermore, the finding is expected to be considered as an input in conducting the Family Well-being development programmed. 
INTERNATIONAL JOURNAL OF ACADEMIC RESEARCH IN ACCOUNTING, FINANCE AND MANAGEMENT SCIENCES

Vol. 10 , No. 3, 2020, E-ISSN: $2225-8329$ @ 2020 HRMARS

The outcome of this study is predicted to facilitate Debt Management and Counselling Agency in formulating new approach and requirement to improve Malaysian financial well-being. This study is likely to reveal as one of the indicators needed for the existing standard, initiative and strategies in increasing the Malaysian Well-being Index as aspirated in the 11th Malaysian Plan. This study strongly supports the 11th Malaysian Plan to strive for a future that is built on sound macroeconomic policy and inclusiveness, so that no Malaysian is left behind., It also improves well-being for all; these include human capital development, green and sustainable growth, infrastructure that supports economic expansion and a citizen-centric public service with high productivity in achieving a level of social well-being compatible with the nation's aspirations. Besides, the research findings are also expected to be used by any government agencies such as Ministry of Women, Family and Community Development in designing programmed related to financial well-being to meet the current financial well-being need.

\section{Conclusion}

This research proposes an index that can be used to assess the level of financial well-being among Malaysian workers. A measure is needed for researchers, policymakers, businesses, and community groups to document the distribution of financial well-being across different segments of society, monitor trends in financial well-being, and evaluate the effectiveness of the policy, product, capability, and behavioural interventions. Therefore, this study fulfils the need by developing an Islamic Financial Well-Being Index (i-FWB Index) for measuring sustainable financial well-being. In conclusion, the central contribution of this research is to propose a new index to measure the financial well-being of Malaysian workers. Besides, this paper also discusses the five major steps in developing i-FWB Index. The propositions steps are referred to previous studies which have been widely used by many researchers in developing a new instrument. The significant theoretical, empirical and practical contributions of this study has also been highlighted and discussed.

\section{References}

Abeytaa, A. A., Routledgeb, C. (2018) The need for meaning and religiosity: An individual differences approach to assessing existential needs and the relation with religious commitment, beliefs, and experiences. Personality and Individual Differences 123. 6-13. https://doi.org/10.1016/j.paid.2017.10.038

Abuseif, S., Abdullah, N. A. (2016) The moderating effect of self-control in the relationship between trait anger and negative affectivity on workplace bullying: a study among nurses in Jordan. European Journal of Business and Management, 8 (2). pp. 75-80

Achtziger, M., Hubert, P., Kenning, G., Raab, L., Reisch. (2015). Debt out of control: The links between self-control, compulsive buying, and real debts. Journal of Economic Psychology, 49, 141-149. https://doi.org/10.1016/j.joep.2015.04.003

AFBES'18. (2018). AKPK Financial Behaviour and State of Finanical Well-being of Malaysian Working Adult. AKPK Financial Behaviour Survey 2018 (AFBES'18).

Amanah, E., Rahardian, D., \& Iradianty, A. (2016). Pengaruh Financial Knowledge, Financial Attitude dan External Locus Of Control Terhadap Personal Financial Management Behavior Pada Mahasiswa S1 Universitas Telkom. E-Proceeding of Management, 3(2), 1228-1235 
INTERNATIONAL JOURNAL OF ACADEMIC RESEARCH IN ACCOUNTING, FINANCE AND

MANAGEMENT SCIENCES

Vol. 10, No. 3, 2020, E-ISSN: 2225-8329 ๔ 2020 HRMARS

Asaad, C. T. (2015). Financial literacy and financial behavior: assessing knowledge and confidence. Financial Services Review, 24 (2), 101-117.

Baumeister, R. F. (2002). Yielding to temptation: Self-control failure, impulsive purchasing, and consumer behavior. Journal of Consumer Research. 28 (4), 670-676. https://doi.org/10.1086/338209

Beckmann, Elisabeth. "Financial Literacy and Household Savings in Romania." Numeracy 6, Iss. 2 (2013): Article 9. http://dx.doi.org/10.5038/1936-4660.6.2.9

Biljanovska, N., \& Palligkinis, S. (2014). Control Thyself: Self-Control Failure and Household Wealth. SSRN Electronic Journal. https://doi.org/10.2139/ssrn.2509080

Bir, J. S. (2016). Knowledge, attitude and their effect on the recently graduated employees' financial management practices and satisfaction. Economic Literature, 12, 69-81. https://doi.org/10.3126/el.v12i0.14889

De Bruin, B. W., Yoong, J., \& Willis, R. (2012). Inappropriate confidence and retirement planning: Four studies with a national sample. Journal of Behavioral Decision Making, 25(4), 382-389. https://doi.org/10.1002/bdm.745

Chaulagain, H., Rodrigues, H., Silva, V., Spacone, E., \& Varum, H. (2015). Earthquake loss estimation for the Kathmandu Valley. Bulletin of Earthquake Engineering, 14(1), 5988. https://10.1007/s10518-015-9811-5

Chen, H., Huang, H. H., Lobo, G. J., \& Wang, C. (2016). Religiosity and the cost of debt Journal of Banking and Finance. 70 70-85. https://doi.org/10.1016/j.jbankfin.2016.06.005

Choi, J. J., Laibson, D., \& Madrian, B. C. (2011). \$100 bills on the sidewalk: suboptimal investment in 401(k) plans. Review of Economics and Statistics, 93(3), 748-

763. https://10.1162/rest_a_00100

Churchill, G. A. (1979). A paradigm for developing better measures of marketing constructs. Journal of Marketing Research, 19 (February), 64-73. https://doi.org/10.1177/002224377901600110

Cohen, A. B., Shariff, A. F., \& Hill, P. C. (2008). The accessibility of religious beliefs. Journal of Research in Personality. 42, 1408-1417.

DeVellis, R. F. (1991). Scale Development: Theory and Applications. Sage Publications, Newbury Park, CA

Eagly, A. H., \& Chaiken, S. (1993). The psychology of attitudes. Orlando, FL, US: Harcourt Brace Jovanovich College Publishers

Ali, F. (2014). Contentment (Qana'ah) and its role in curbing social and environmental problems. Islam and Civilisational Renewal. 5 (3), 430-445. https://doi.org/10.12816/0009871

Fudenberg, D., Levine, D. K. (2006). A dual-self model of impulse control. American Economy Review. 96 (5), 1449-1476. https://doi.org/10.1257/aer.96.5.1449

Fujita, K., Trope, Y., Liberman, N., Levin-Sagi, M., (2006). Construal levels and self-control. J. Pers. Soc. Psychol. 90 (3), 351-367. https://doi.org/10.1037/0022-3514.90.3.351

Finney, A. (2016). Defining, measuring and predicting financial capability in the UK: A Technical Report. Money Advice Service's Financial Capability.

Garman, E. T., \& Forgue, R. E. (2006). Personal finance (7th ed.). Boston: Houghton Mifflin Co. Gathergood, J. (2012). Self-control, financial literacy and consumer over-indebtedness. Journal of Economic Psychology, 33(3), 590-602. https://10.1016/j.joep.2011.11.006 
INTERNATIONAL JOURNAL OF ACADEMIC RESEARCH IN ACCOUNTING, FINANCE AND

MANAGEMENT SCIENCES

Vol. 10, No. 3, 2020, E-ISSN: 2225-8329 @ 2020 HRMARS

Ghazali, M. S., Alwi, S. F. S., Aziz, N. N. A., \& Hazudin, S. F. (2020). Pathway to financial well-being: A review of the role of psychological factors. Environment-Behaviour Proceedings Journal, 5 (13), 55-61. https://doi.org/10.21834/e-bpj.v5i13.2063

Halim, E. K. Y., and Astuti, D. (2015). Financial stressors, financial behavior, risktolerance, financial solvency, financial knowledge and financial satisfaction. Journal of Finance FINESTA, 3(1), 1923.

Hastings, J., Madrian, B., and Skimmyhorn, W. (2013) Financial Literacy, Financial Education, and Economic Outcomes. Annual Review of Economics, 5, 347-373. https://doi.org/10.1146/annurev-economics-082312-125807

Herdjiono, I., \& Damanik, A. (2016). Pengaruh financial attitude, financial knowledge, parental income terhadap financial management behavior. Jurnal Manajemen Teori Dan Terapan, 9 (3), 226-241.

Hilgert, M. A., Jeanne, M. H., \& Sandra, G. B. (2003). Household Financial Management: The Connection between Knowledge and Behavior. Federal Reserve Bulletin. 89 (7), 309-322.

Hogarth, J. M., Beverly, S. G., and Hilgert, M. (2003). Patterns of financial behavior: implications for community educators and policy makers. Federal Reserve System Community Affairs Research Conference, 1 - 29.

Husniyah, A. R., \& Fazilah, A. S. (2011). Factors contributing to financial stability of urban and rural families. Pertanika Journal of Social Sciences \& Humanities. 19 (1), 99-112.

Huston, S. (2010). Measuring Financial Literacy. Journal of Consumer Affairs, 44, 296-316. http://dx.doi.org/10.1111/j.1745-6606.2010.01170.x

Jappelli, T., and M. Padula (2011). Investment in Financial Literacy and Saving Decisions. CSEF Working Paper 272, University of Salerno

Javanmard, G. H. (2013). Religious Beliefs and Resilience in Academic Students. Procedia Social and Behavioral Sciences, 84, 744-748. https://doi.org/10.1016/j.sbspro.2013.06.638

Joo, S. (2008). Personal financial wellness. In J. J. Xiao (Ed.). Handbook of consumer finance research (p. 21-33). New York: Springer.

Kempson, E., Finney, A., \& Poppe, C. (2017). Financial Well-Being: A Conceptual Model and Preliminary Analysis. Consumption Research. Norway - Sifo Oslo and Akershus University College Of Applied Sciences.

Kim, J., Garman, E. T., \& Sorhaindo, B. (2003). Relationships among credit counselling clients financial well-being, financial behaviours, financial stressor events, and health. Financial Counseling and Planning, 14, 75-87.

Lusardi, A., \& Mitchell, O. S. (2011). "Financial Literacy and Planning: Implications for Retirement Wellbeing." In Financial Literacy: Implications for Retirement Security and the Financial Marketplace. Oxford: Oxford University Press

Lajuni, N., Bujang, I., \& Karia, A. A. (2018). The Effect of Religiosity, Financial Knowledge, and Financial Behaviour on Financial Distress Among Undergraduate Students. Proceedings of the 2nd Advances in Business Research International Conference, https://doi.org/10.1007/978-981-10-6053-3_17.

Masud, J. (2007). Testing of Malaysia's Financial Well-Being Scale. Paper presented in the Seventh Biennial Conference 2007 ACFEA, Purajaya, Malaysia. 4-7 July. 
INTERNATIONAL JOURNAL OF ACADEMIC RESEARCH IN ACCOUNTING, FINANCE AND MANAGEMENT SCIENCES

Vol. 10, No. 3, 2020, E-ISSN: 2225-8329 @ 2020 HRMARS

Misra, R., Srivastava, S., \& Banwet, D. K. (2019). Do religious and conscious investors make better economic decisions? Evidence from India. Journal of Behavioural and Experimental Finance. 22 (2019) 64-74. https://doi.org/10.1016/j.jbef.2019.02.003

Mokhtar, N., \& Husniyah, A. R. (2017). Determinants of Financial Well-Being among Public Employees in Putrajaya, Malaysia. Pertanika Journal of Social Science and Humanities, 25 (3), 1241-1260.

Moltafeta, G., Mazidib, M., \& Sadatic, S. (2010). Personality traits, religious orientation and happiness. Procedia Social and Behavioural Sciences. (9), 63-69. https://doi.org/10.1016/j.sbspro.2010.12.116

Murugiah, L. (2016) The level of understanding and strategies to enhance financial literacy among Malaysian. International Journal of Economics and Financial Issues. 6 (3S).

Mokhtar, N., Rahim, H. A., Fazli, M. F., and Talib, M. A. (2015) . Financial well-being among public employees in Malaysia: A preliminary study. Asian Social Science Journal 11(18). https://doi.org/10.5539/ass.v11n18p49

O'Neill, B., Sorhaindo, B., Xiao, J., \& Garman, T. (2005). Financially distressed consumers: their financial practices, financial well-being and health. Westerville: Association for Financial Counselling and Planning Education.

Othman, M. A. (2017). Kajian faktor-faktor literasi, sosialisasi dan tingkah laku pengguna terhadap perancangan kewangan islam berdasarkan teori tingkah laku yang terancang dalam kalangan kakitangan awam di Wilayah Persekutuan, Putrajaya. Phd Thesis, Akademi Pengajian Islam University Malaya Kuala Lumpur

Prawitz, A. D., Garman, E. T., Sorhaindo, B., O'Neill, B., Kim, J., \& Drentea, P. (2006). InCharge financial distress/financial well-being scale: development, administration, and score interpretation. Financial Counseling and Planning, 17 (1), 34-50. https://doi.org/10.1037/t60365-000

Prendergast, S., Blackmore, D., Kempson, E., Russell, R., \& Kutin, J. (2018). Financial well being: A survey of adults in Australia. https://www.anz.com/resources/2/f/2f348500-38a2-4cfe8411-060cb753573d/ financial-wellbeing-aus18.pdf?MOD=AJPERES.

Qutaibaa and Tamie. (2010). Self-control and a sense of social belonging as moderators of the link between poor subjective well-being and aggression among Arab Palestinian adolescents in Israel. Procedia Social and Behavioral Sciences 30, 1058-1069. https://doi.org/10.1016/j.sbspro.2010.07.284

Rha, J. Y., Montalto, C. P., Hanna, S. D. (2006). The effect of self-control mechanisms on household saving behavior. J. Financ. Couns. Plan. 17 (2), 3-16.

Russell, R., Stewart, M., \& Cull, F. (2015). Saver Plus: A decade of impact. http://www.anz.com/resources/a/7/a7ab5ce8-9cf1-42f6 8a02- 46dfe2fe5194/saver-plusdecade-impact.pdf

Rutherford, L. G., \& Wanda, S. F. (2010). Financial wellness of young adults age 18-30. Family and Consumer Sciences Research Journal, 38(4), 468-484. https://doi.org/10.1111/j.15523934.2010.00039.x

Sabri, M. F., \& Falahati, L. (2003). Predictors of financial well being among Malaysian employee: Examining the mediate effect of financial stress. Journal of Emerging Economies and Islamic Research, 1 (3), 1-16. 
INTERNATIONAL JOURNAL OF ACADEMIC RESEARCH IN ACCOUNTING, FINANCE AND MANAGEMENT SCIENCES

Vol. 10, No. 3, 2020, E-ISSN: 2225-8329 @ 2020 HRMARS

Sabri, M. F., Paim, L., Falahati, L., \& Masud, J. (2013). Determinants of employees' financial wellbeing: The moderation effect of work sectors. Malaysian Journal Of Consumer And Family Economics, 16 (1), 91-105.

Shim, S., Xiao, J. J., Barber, B., \& Lyons, A. (2009). Pathways to lifesuccess: A conceptual model of financial well-being for young adults. Journal of Applied Developmental Psychology. 30,708-723. https://doi.org/10.1016/j.appdev.2009.02.003

Selltiz, C., Wrightsman, L. S., \& Cook, S. W. (1976). Research Methods in Social Relations, Canada: Holt, Rinehart \& Winston of Canada Ltd

Shweder, R. A. (1991). Thinking through cultures: Expeditions in cultural psychology. Cambridge, MA: Harvard University Press.

Sipon, S., Othman, K., Ghani, Z. A., \& Radzi, H. M. (2014). Procedia - Social and Behavioural Sciences. (140). 300 - 306. https://doi.org/10.1016/j.sbspro.2014.04.424

Stillman, T. F., Fincham, F. D., Vohs, K. D., Lambert, N. M., Phillips, C. A. (2012). The material and immaterial in conflict: spirituality reduces conspicuous consumption. Journal of Economic Psychology. 33, 1-7. https://doi.org/10.1016/j.joep.2011.08.012

Sumarwan, U., and Hira, T. K. (1992). Credit, saving and insurance practice influencing satisfaction for financial emergencies among rural households. Home Economics Research Journal, 21 (2), 206 - 227. https://doi.org/10.1177/1077727X9202100205

Stromback, C., Lind, T., Skagerlund, K., Vastfjall, D., Tinghog, G. (2017), Does self-control predict financial behavior and financial well-being? Journal of Behavioral and Experimental Finance. http://dx.doi.org/10.1016/j.jbef.2017.04.002

Williams, F. L. (1993). Financial counseling: Low-income or limited-income families. In V. S. Fitzsimmons (Ed.), Economic changes: Challenges for financial counseling and planning professionals. Proceedings of the Association for Financial Counseling and Planning Education, 121-145.

Wotruba, T. R., \& Wright, P. L. (1975). How to develop a teacher-rating instrument: A research approach. Journal of Higher Education, 46 (6), 653-663. https://doi.org/10.1080/00221546.1975.11778667

Xiao, J. J., Sorhaindo, B., \& Garman, E. T. (2004). Financial behaviors of consumers in credit counseling. International Journal of Consumer Studies. 30(2):108-121

Xiao, J. J., Chen, C., \& Chen, F. (2013). Consumer financial capability and financial satisfaction. Social Indicators Research. https://doi.org/10.1007/s11205-013-0414-8

Xiao, J. J. (2013). Family economy ic well-being. In G. W. Peterson, \& K. R. Bush (Eds.), Handbook of Marriage and the Family (pp. 573-610). New York: Springer. https://doi.org/10.1007/978-14614-3987-5_24

Yilmaz, O., \& Bahçekapil, H.G. (2015) Without God, everything is permitted? The reciprocal influence of religious and meta-ethical beliefs. Journal of Experimental Social Psychology, 58, 95-100. https://doi.org/10.1016/j.jesp.2015.01.003

Zaimah, R., Masud, J., Haron, S. A., Awang, A. H., Sarmila, M. S., Azima, A. M., \& Saad, S. (2018). Financial Well-being of Married Workers in Malaysia. International Journal of Academic Research in Business and Social Sciences, 8(13) Special Issue: Community Development \& Social Mobility, 169-177. 